\title{
The Visual (dis)Function in Neurological Diseases
}

\author{
Marcelo Fernandes Costa* \\ Department of Experimental Psychology, University of São Paulo, São Paulo, SP, Brazil
}

\begin{abstract}
Visual functions are frequently impaired in neurological diseases. However, insufficient information regarding the visual function dimensions is available reflecting the sparse investigations in both research and clinical works. Visual acuity, visual field and oculomotor function are the only few functions evaluated in neurological diseases and in almost all cases they are worst reflections of the visual word of the patient. We present a series of studies of visual functions in neurological diseases that are in line with a more translational research investigating the basic functions and relating them to the neurological impairment. Future perspectives are discussed to support upcoming researches and therapeutics more efficient and scientifically based.
\end{abstract}

Keywords: Neurological diseases; Visual impairment; Visual psychophysics; Visual electrophysiology; Visual perception

\section{Introduction}

The visual system evolved to recognize objects in the environment from patterns of light and dark in retina by processing the luminance differences (contrast) at the boundaries of objects and their backgrounds, chromatic contrast, depth, texture and dynamic events like motions.

Three major pathways involved in the visual processing: the Magnocellular (MC), the Koniocellular (KC) and the Parvocellular (PC) pathways [1-3]. Different characteristics of the MC, KC and PC responses to stimulus size, color and time of presentations are reported. $\mathrm{MC}$ pathway is vigorously activated to low spatial frequencies (i.e. large stimulus elements) whereas the PC pathway is activated to high spatial frequencies (i.e. small stimulus elements) [4,5]. The MC pathway is also related to responses to objects with low contrast and rapidly changes in the stimuli, while PC pathway is relatively insensitive to movement processing slowly changing, clearly defined patterns or objects and redgreen chromatic channel [5].

The Koniocellular pathway is activated to low spatial frequencies, high temporal frequencies and a specific subgroup (K3) is related to the chromatic blue-yellow channel [6,7]. Thus, those differential properties of the MC, KC and PC pathways make it possible to infer the relative role of those pathways in the capacity of discriminate spatial details, contrast levels, chromatic and motion perception.

These visual functions can be assessed by psychophysical and electrophysiological procedures. Both are non invasive methods with high sensitivity to detect subtle changes in visual performance which turns those both methods in powerful techniques to detect impairments in the visual pathways and also in monitoring therapeutic evolution of patients. However, as you will see, even in the most of the neurological diseases as cerebral palsy, multiple sclerosis and others, the knowledge of the visual pathway impairments are poorly investigated as well as the use of the visual functions evaluations in the diagnostic of diseases and therapeutic follow up procedures.

\section{Cerebral Palsy}

Cerebral palsy designates a large group of motor and sensory defects caused by a non-progressive lesion of the brain that occurred early in life. These defects are permanent, but they may exhibit some plasticity. The most frequent and severe motor impairment in such children is spastic cerebral palsy (SCP) [8].
Cognitive alterations, mental retardation, epilepsy and hearing loss are frequently associated with SCP [9]. In addition, ophthalmological disturbances such as oculomotor abnormalities, retinopathy and refractive error are often observed [10-14]. The visual impairment can be secondary to these ophthalmologic abnormalities but more often they are due to damage of the central visual pathway.

The different etiologies make a hard work to find a correlation between cerebral damage, even in the early visual pathways, and the visual impairment. Leukomalacia periventricular is one of the most damage in the white matter affecting the optic radiation associated with visual impairment in SCP [15-18]. Other findings like brain abnormalities in the fMRI [19], parietal posterior and cingulate cortex [20] and abnormal structural thalamus-cortical pathway in diffusion tensor imaging (DTI) [21] in SCP children had also been correlated with the visual impairment. However, other studies failed in found the causal relation between cerebral damage and the visual function impairment since lesions caused by neonatal hypoxia-ischemia could be so small that the image techniques could not be able to detect them [22-24].

The visual acuity is the most frequent visual function studied and is related to the discrimination ability to spatial elements in the visual scene. Almost all studies shown reductions in visual acuity of the SCP children when compared with the normal children using psychophysical $[10,19,22,25,26]$, and electrophysiological procedures like pattern reversal visual evoked potentials [27-30]. Since visual acuity measured the minimum separation of spatial elements, the PC pathway is related to this function $[31,32]$.

The detection of cortical impairment by topographical electrophysiology or neuroimaging evaluations like magnetic resonance frequently did not found causal relation between cerebral and functional damages. Diagnosis of brain lesion in MRI images can be considered as a potential finding for visual impairment [33] but the opposite is

*Corresponding author: Marcelo Fernandes Costa, University of São Paulo Universidade de São Paulo, Brazil, Tel: + 55113091 1915; E-mail: costamf@usp.br

Received March 28, 2013; Accepted May 10, 2013; Published May 20, 2013

Citation: Costa MF (2013) The Visual (dis)Function in Neurological Diseases. J Neurol Neurophysiol S4:004 doi:10.4172/2155-9562.S4-004

Copyright: ( 2013 Costa MF. This is an open-access article distributed under the terms of the Creative Commons Attribution License, which permits unrestricted use, distribution, and reproduction in any medium, provided the original author and source are credited. 
not true. A more often relation found is regarding the impairment in the visual acuity that has been positively correlated with the motor impairment. We evaluated 37 SCP children, classified in tetraplegic, diplegic and hemiplegic, according to their motor dysfunction, and found higher visual acuity impairment in SCP children with higher score in the GMFCS [29]. Other studies only pointed a worst visual acuity in the more severe motor disabilities $[10,34]$.

Other visual pathways were not selectively evaluated. Contrast sensitivity and motion perception were not studied. Both had a high relation with the MC pathway since evaluate time related visual processing and low spatial frequencies. Inferences for a preserved MC pathway in SCP come from the studies of May et al. and Marozas et al. $[35,36]$. These studies reported a significant improvement in performance of visual perceptual tests using a dynamic patterns reversal stimulation comparing to a static standard stimulation for visual acuity. Color vision could suggest a possible KC pathway impairment but again, only one study was found [37] and the results presented were inconclusive. Short-wavelength cones are more sensible to variations in oxygen levels and since perinatal hypoxia is the most frequent etiology, the absence of color vision deficits is probably due to shortage of scientific studies. It is quite difficult to believe that only a selective portion of the visual pathway (PC pathway) is impaired in SCP. Oculomotor function impaired $[38,39]$ and some findings related to spatial vision, more related to MC pathway, suggest a more diffuse cortical damage.

\section{Duchenne Muscular Dystrophy}

Duchenne muscular dystrophy (DMD), which affects 1:3,500 newborn males, [40-43] is the most common form of progressive muscular dystrophy disease. It is caused by a deficiency in the protein called "dystrophin". The dystrophin gene, at Xp21, has 79 exons [44]. DMD is caused by deletions in the dystrophin gene in $60 \%-65 \%$ of patients, by duplications in $5 \%-10 \%$, and by point mutations or small rearrangements in the remaining $20 \%-30 \%$. The main pathological effects caused by mutations in the dystrophin gene are in the skeletal and cardiac muscles, although dystrophin is present in several other tissues of the body, including a widespread distribution in the nervous system [45].

In addition to full-length dystrophin, four other shorter proteins are transcribed from the DMD gene: Dp260 (transcripts spliced to exon 30), Dp140 (transcripts spliced to exon 44), Dp116 (transcripts spliced to exon 56), and Dp71 (transcripts spliced to exon 63) [46-50].

In the retina, dystrophin is expressed at the level of the outer plexiform layer (Dp260) in the inner limiting membrane (Dp71) [46-54]. Dp260 is also found at the cone pedicle, in the region of the ribbon synapse [55-59]. Electrophysiological studies showed that Dp260 is essential for the physiology of the retina, since patients with DMD and deletions downstream of exon 30 had serious impairment in both scotopic and photopic responses obtained by full-field electroretinogram (ERG) [49,60-72]. The role of Dp71 in the retinal electrophysiology is still unknown. In the work of Claudepierre et al. [52] dystrophin was associated with the Muller cells' contribution to the b-wave of full-field ERG. Dp427 and Dp140 are also present in mouse retina but do not appear to contribute to the ERG [47]. The specific site of the dystrophin in retina impairs the signaling of photoreceptors to the bipolar and ganglionar cells the appearance of light, but preserves the signaling of light disappearance.

Previous studies on color vision in patients with DMD or Becker muscular dystrophy (BMD), based on Ishihara and American Optical
Hardy-Rand-Rittler ( $\mathrm{AO} \mathrm{H}-\mathrm{R}-\mathrm{R}$ ) tests, found that the proportion of red-green defect in this group [73,74] was in accordance with the proportion observed for the normal population.

We report, for the first time to our knowledge, that red-green color vision defect is highly prevalent in patients with DMD with deletions downstream of exon 30 [75-78]. Since all but one (11/12) of the patients with deletions upstream of exon 30 had normal color vision, the present study suggests that the color defect is related to possible functional damage associated with Dp260, the dystrophin isoform located in the outer plexiform layer [46, 47,49,50,79]. Previous studies on evaluation of visual functions in patients with DMD reported normal ophthalmologic conditions as well as visual functions, including visual acuity, ocular motility, and color vision [73, 80,81].

The incidence of color vision defect among the patients with DMD was 54\% (24/44); of these 24 patients, 21 had losses of the red-green type, whereas only 3 , or $7 \%$, had diffuse color vision loss. This is a much higher proportion than expected for congenital protan and deutan defects, which occur in $7 \%-10 \%$ of the male population [82]. Recently, we also shown that chromaticity discrimination could suggest the region of gene deletion in DMD children with no deletion detected. Since color vision is dependent of deletions downstream exon 30 , chromaticity impairment suggest that gene impairment is occurring in those region [83].

The mechanisms underlying this color vision loss are not known. Patients with DMD present selective impairment in a function mediated by a specific neural pathway-the PC pathway, which mediates redgreen color vision. This pathway is initiated by the response of the $\mathrm{L}$ and $\mathrm{M}$ cones and comprises a neural network from the retina to the lateral geniculate nucleus and, from there, to several cortical levels. The MC pathway, which mediates achromatic functions, is also initiated by inputs from the $\mathrm{L}$ and $\mathrm{M}$ cones [84,85]. In the MC pathway, the signals from the $\mathrm{L}$ and $\mathrm{M}$ cones are added to convey the information of luminance, whereas, in the PC pathway, the $\mathrm{M}$ and $\mathrm{L}$ cones signals are compared, and the neural response expresses their difference, to convey the chromatic information. Chromatic processing includes, in addition, the blue-yellow pathway in which the S-cone signals are compared with the added inputs of the $\mathrm{L}$ and $\mathrm{M}$ cones [3].

Our findings differ from the result of the work of Benoff et al. [86] who showed that there was MC but not PC impairment in the VEPs of patients with DMD. This disagreement could be due to two factors: (1) The MC pathway is tuned to detect luminance stimuli as the chessboard stimuli that varied in the size of the elements and in the contrast level used in that study. Although the PC pathway also exhibits a response to luminance stimuli, the chromatic stimuli, either red or green, produces the most vigorous activation. (2) The MC pathway collects the response of many more cones than the PC pathway. Since the VEP is a cortical mass response of small amplitude, differences could be more evident in responses mediated by the $\mathrm{MC}$ rather than $\mathrm{PC}$ pathway.

However, in recent studies we have been found significant reduction in spatial contrast sensitivity of almost one log unit compared with the control group is fundamentally important for clinical application. Unfortunately, the clinical evaluation of spatial visual function is limited to the measurement of visual acuity. For this reason, DMD patients were regarded as having normal vision by Sigesmund et al. [73].

In our work [87], contrast sensitivity was also tested for temporally modulated stimuli. We found a reduction in the detection of luminance contrasts for the two lowest temporal modulations (i.e., 1 and $2 \mathrm{~Hz}$ ). 
The battery of spatial and temporal contrast sensitivity tests that we used supports the hypothesis that the PC pathway is the most affected visual pathway in DMD. With regard to spatial contrast sensitivity, we found impairment at all spatial frequencies, reflecting both $\mathrm{MC}$ and PC pathways impairment. However, temporal contrast sensitivity showed a reduction for the low temporal frequencies (i.e., 1 and $2 \mathrm{~Hz}$ ), indicating selective PC pathway impairment.

\section{Hydrocephalus}

The clinical features of hydrocephalus, especially in the first months of life, is the increase in cranial volume detected by frequent measurements of head circumference, together with the help of appropriate curves and by imaging studies [88].

Children diagnosed with hydrocephalus often present, in addition to visual changes and ocular signs that are very evident from the earliest stages of the disease, failures in the development of cognitive functions. However, the role of the neuropathological abnormalities and complications of hydrocephalus in the genesis of those changes is still poorly understood [89].

The true incidence of vision loss is not known in this population. There are several studies on the complications of the shunt, but the loss of vision as a complication has not been mentioned in any of these $[90,91]$. Therefore the aim of our study is to measure visual acuity and verify the effectiveness of the method in children diagnosed with hydrocephalus, with or without shunt and if the time using the derivation presents reflections on visual function, relating possible complications of the shunt and changes in the visual acuity.

The normal visual acuity depends on the integrity of the central nervous system Increased cranial pressure due to hydrocephalus is one of the factors that most often negatively affects the visual function. One of the first studies to describe the visual impairment as a result of hydrocephalus was published in 1768 by Robert Whytt. In that work, the authors found an incidence of strabismus between $60 \%-75 \%$ of children with hydrocephalus [91] a higher than in normal population (around 3\% - 4\%).

The increase in the intracranial pressure leads to a compressive stimulation of the brainstem nucleus generating strabismus $[90,92]$ or tonic upward-gaze [93], chiasmal compression leading to visual field defect $[94,95]$, and visual pathway damage [96] including the optical radiation due to ventricular enlargement [97].

The assessment of visual acuity in children with hydrocephalus has not been frequently studied and, as a logical consequence, there are few studied regarding to the visual functions and even fewer that follow those children as we did. The studies involving children with a diagnosis of hydrocephalus are mostly series of retrospective case and they consider different etiologies as a unique group [98,99].

Among the fifty-five children studied forty-five were derived. Considering the complications arising from the presence of periventricular derivation, we noticed that a large proportion of children in this group (a total of thirty-seven) suffered some complication. Considering the complications presented in our sample, we found that thirty-six were due to obstruction and infection that occurred between the visual acuity measurements.

Kliemann and Rosemberg [100] claim in their study that the infection and mechanical malfunction of the shunt system are the main complications of periventricular derivation. Mechanical complications such as obstruction of the drainage catheter have been reported with a frequency between $30 \%$ and $60 \%$, occurring most frequently in the first two years after bypass.

The infection rate of the drainage system varies between $2 \%$ and $15 \%$, with a major influence on morbidity and quality of life of patients and in mortality risk that could be as higher as 30\%-40\%. An interesting finding in our study was the fact that the group with no shunt complications presented better values of visual acuity compared to those group in which the complications had occurred.

In our study [101], another important factor related to complications and their impact on the visual system is the fact that the more complications in the shunt system the greater the reduction in the development of visual acuity with the passing of time, since the values of visual acuity values remained similar against the expectation of an evolution of this function, normally observed in normal children with those ages.

Children who experienced complications in the period comprising two consecutive tests of visual acuity, the values measured were lower than those children who had complications in only one examination. Again, we found in the literature which correlates the number of complications of periventricular derivation with visual function over time.

We obtained results showing that the time between diagnosis and surgery to perform the bypass impairs the visual function. We are lead to conclude it since children who had the latency greater than 15 days between diagnosis and the need to the bypass procedure, had the worst values of visual acuity. This finding is of great impact and gives more information to consider one that can help medical staffs when deciding on the procedures to be performed in those children, mainly surgeries.

Even hydrocephalus have been a disease known for centuries and have as main signs the ocular and visual impairments the only visual function studied in this population is visual acuity. Thus, it is only possible to affirm the existence of damage in the PC pathway. However, visual aspects which could give indications of changes involving other visual pathways such as $\mathrm{MC}$ and $\mathrm{KC}$ were not properly investigated.

\section{Multiple Sclerosis}

Multiple sclerosis (MS) is the most common disabling neurological disease in young adults and the visual pathway is particularly susceptible to damage [102,103]. Visual involvement was first described as early as 1890 by Uhthoff, cited in Volpe [104,105]. In MS, a spectrum of pathologies exists, ranging from acute optic neuritis, with relatively sudden loss of vision, to subtle sub-clinical disturbances evident only with neurophysiologic or psychophysical testing [106,107].

The neurological impairment in multiple sclerosis is highly variable from only inflammatory markers in blood exams to disseminated brain lesions $[108,109]$. The most common ophthalmologic disease associate is the optical neuritis [110,111], but retrobulbar neuritis [112], optical atrophy $[113,114]$ and oculomotor manisfestations like strabismus $[115,116]$, pendular nystagmus $[117,118]$ and internuclear ophthalmoplegia [103] have also been related to the MS.

Peripheral constriction in visual fields is a common find in MS patients, frequently related to a cortical atrophy or retrochiasmal damage in visual pathway [116,119-122]. Additionally, spatial and temporal resolutions are also affected since the demyelination insult impairs the brainstem and also subcortical areas [123-127] evidenced by imaging studies [128]. 
Color vision testing in neurophthalmology is traditionally carried out with Ishihara pseudoisochromatic plates (Ishihara), Farnsworth D-15 test (D-15), Lanthony D-15 desaturated test (D-15d), and the Farnsworth-Munsell 100 hue test (FM-100). All of these tests are effective in detecting congenital color deficiencies, and are useful for monitoring neurophthalmologic dysfunction. Despite its extensive use, the Ishihara was not designed for detecting defects along the blueyellow axis.

Optic neuritis is frequently present in ophthalmological evaluation in patients with MS and can affect one or both eyes. Color vision impairment has been observed in subjects with no history of optic neuritis and tends to be more impaired than luminance sensitivity [129-132]. A number of investigators have attempted to determine if there is a selective effect on red-green or blue-yellow mechanisms in optic neuritis. Using psychophysical methods, a number of studies found no preference for loss in a specific chromatic channel $[129,130]$.

Pupil response to a chromatic stimulus has also been used as an additional tool in evaluating this patients' group evaluation. Barbur et al. [133] found abnormal pupil response in optic neuritis with the color response being more affected than the achromatic reflex, and even following the recovery of vision, after a optic neuritis attack, the pupil response remains abnormal.

Our study show statistically significant losses in chromatic discrimination in MS patients as assessed by the CCT [134]. The impairment is present in MS even with no history of optic neuritis [131], although the ON group had more impairment. Both patient groups manifested significant losses along the protan and tritan axes, and the ON group had losses along the deutan axis as well. Such a tendency would suggest a greater impairment in the PC pathway, consistent with some results with other optic neuropathies such as Leber's hereditary optical neuropathy [135], but not others [136-141].

\section{Mercury Vapor Intoxication}

Impairment of visual functions has been studied in patients exposed to mercury. These studies have been shown partial loss of color vision in workers exposed to several solvents and to metallic mercury [142-148].

The effect of mercury in the central nervous system is very aggressive since mercury is found in all CNS structure including cortex $[149,150]$, brainstem, cerebellum [151], putamen [152] and retina [148,149,153].

Color vision and contrast sensitivity (CS) impairment were also found in fish-eating Amazonian populations due to mercury release from gold-mining activities. The loss of color vision and CS has been demonstrated in these populations, at methyl mercury levels of contamination below $50 \mathrm{mg} / \mathrm{g}$ of total hair $\mathrm{Hg}$, which is traditionally considered the threshold for clinical effect [145,154-156]. The measurement of CS in 7-yr old children with prenatal exposure to methylmercury also showed impairment in their CS [157]. CS impairment relating exposure to mercury vapor was reported by Hudnell et al. [158] in an evaluation of children living in polluted areas, who were exposed to mercury vapor. Psychophysical measurement of their CS showed impairment in low to middle spatial frequencies.

We have been performing psychophysical measurements of CS in adults with occupational exposure to mercury vapor. Workers at fluorescent-lamp manufacturing plants $[140,148,159]$ had a uniform reduction in the luminance CS function from low to high spatial frequencies measured psychophysically. Measurements using sweep visual evoked potential (sVEP) showed a reduction in luminance CS in low to middle spatial frequencies [160]. Psychophysical chromatic red-green and blue-yellow CS were also tested and showed a reduction for low and middle spatial frequencies. Dentists exposed to mercury vapor due to the use of dental amalgam in restorative work showed a diffuse impairment (comprising low to high spatial frequencies) in CS measured psychophysically for luminance and for chromatic stimuli [161]. Those results also confirm psychophysical finding from other authors measuring the CS in methylmercury intoxicated patients $[145,156,162]$.

The preliminary results measured in 14 patients, and those of the current study, are the only sVEP evidence of mercury vapor effects on CS of which we are aware [159]. In a following paper, we evaluated 41 patients [160]. Our results confirm and extend those of the preliminary study showing reduction of luminance spatial CS at middle and low spatial frequencies. CS in patients was reduced primarily at low and middle spatial frequencies, but also at high spatial frequencies in severe cases [145,154-156]. Other studies of visual function in mercury vapor intoxication have focused in color vision aspects [142-144,148,163].

Our electrophysiological results showing impairment in CS constitutes indication of damage in the visual neural pathways by the mercury vapor exposure. The presence of asymmetry in almost all patients strongly suggests a retinal effect of the mercury rather than a cortical effect since both sides of the visual cortex receives information coming from the both eyes. Our data are in line with our previous electroretinogram results showing impairment in retina function of these patients in full field and multifocal ERG measurements [148]. They also agree with morphological and image studies showing the mercury deposits in primates in retina $[164,165]$ and in the human visual cortex [152,166-168].

\section{Traumatic Cranial Injury}

Impairment of visual functions is a common found in patients with traumatic brain injury (TBI). The ocular alterations includes since eye surface alterations like the dry eye disease [169] as eye movement impairment saccade or pursuit dysfunction, the third, fourth, or sixth cranial nerve palsy, visual field deficit, visual spatial inattention/neglect, vestibular dysfunction and nystagmus $[170,171]$.

Visual functions are poorly investigated in head injuries. The main functions are visual acuity and visual perimetry [172-174]. In general, visual acuity function is well preserved or normal or closeto-normal, in traumatic brain injuries [175] even in cases of bilateral hemianopia outcome [176]. However, the complexity and the high variability of brain lesions that can lead to visual impairment become more interesting functional studies. Unfortunately, few studies analyze other visual functions such as contrast sensitivity, color vision, depth perception and movement $[177,178]$. Only one study evaluated the distance perception of mild TBI subjects. The authors found a slightly reduction for stereoacuity in those subjects compared to normal [179]. Most studies limited to findings of gross ocular motility, pupillary reflexes and anatomical changes of eyeballs. Some studies report impairment in vergencial movements $[170,180]$, some related to abnormal accommodation $[181,182]$.

The oculomotor performance during reading has been reported impaired in TBI subjects $[183,184]$. In addition, the Critical Flickering Fusion has been found reduced in subjects with TBI measured psychophysically. The authors concluded that the decrease in sensitivity to flickering stimuli was related to the visual pathway damage [182] Those stereoacuity, eye movement during reading and the reduction 
in the critical flickering fusion findings strongly suggest MC pathway impairment since the binocular spatial integration oculomotor system and the temporal processing are processed by their cells.

VEP are rarely used and even when they are, its validity is restricted by the fact that their analysis only be related to the physiological activity of the primary visual pathway [185]. Visual functions such as visual acuity, contrast sensitivity and motion perception are measures of functional and visual activity could certainly tell us much more about the functional status of the vision and not just an indication of the physiology of the primary visual pathway, as some studies have been suggesting [186].

When we think about the underlining processes of visual rehabilitation, we found that the procedures are aligned with the visual measurements in the assessment and therefore only found visual rehabilitation activities in order to improve visual acuity and visual field [187-195]. Still, there are few studies that diagnose or measures that apply to periodic visual tracking rehabilitation treatments in patients with brain trauma.

\section{Future Perspectives}

Visual changes in head injuries are frequent events but still treated somewhat important, is in the process of understanding their pathophysiological changes, either as a subsidy for the subsequent visual rehabilitation. The multiple aspects of visual impairment as spatial and temporal visual functions, reducing the visual abilities and the oculomotor alterations damaging eye movements impairing eye-gaze and reading are evidences for alert us to think in visual impairment, even in mild TBI.

Certainly, future studies should consider increasing the possibility of expanding to more complete understanding of the visual changes in these health conditions. Knowing how they are all visual dimensions allowed the development and planning approaches safer diagnostic and therapeutic rehabilitation.

The first step should be towards understanding the changes that occur in diseases and their impact on vision. For example, we show that there is a very high correlation between the severity of motor and visual impairment in cerebral palsy $[27,28,75,196]$. In cerebral palsy children, contrast sensitivity function for both spatial and temporal aspects are not studied as related functions of depth perception, motion perception and color vision. Our data also point to important maturational changes of the nervous system in infants with bronchopulmonary dysplasia, since they exhibit a delay in the appearance and quality of executable rights of eye movements compared with normal babies (Pereira \& Costa, in press). Duchenne Muscle Dystrophy children had more evident impairments in their PC and a weaker in MC visual pathways but a normal KC pathway $[77,78,87]$. It is important to stress here that our studies contribute to understand the physiological and behavioral effects of different location sites of the lesions. In children with Duchenne had a visual impairment that starts at retina level, differing from cerebral palsied children and multiple sclerosis patients in which the damage is more located in higher levels of the visual pathways.

It is of paramount importance to know the fact that children with hydrocephalus had changes in their visual acuity. However, the most impressive is related to complications. Whenever a child needs new surgery to maintain its drain valve, their visual functions suffer a loss of quantity and quality. Two important consequences of this can be directly derived from our result. The first is the fact that multiple surgeries and interventions lead to loss of primary brain functions, such as the ability to separate visual elements in space. Hence we can assume that possibly, even more severe impacts may be occurring in higher-order cortical functions since these are direct dependents of low-level information processing.

Memory, attention, language, visuospatial functions, all certainly will have some degree of impairment in when most basic functions are impaired [197-204]. Although there are processing in parallel, in those cases, the hierarchical processing is much stronger and influencer. The second point concerns the very fact that the visual system can be used as a direct indicator of the patient's neurological status. Eye movements are related to functions such as attention, learning and search; pupil changes are present in judgment, reasoning and decisionmaking; flashing the amount is dependent on the attentional status and conducting high level cognitive tasks such as solution problems and making decisions. In this direction, we have been found alterations in neuropsychological tests for visual memory, visuospatial attention related with performances and scores in visual function tests in mercury vapor occupationally intoxicated patients [205,206].

The knowledge of different visual functions can help us understand what levels of change more dependent on sensory inputs, whereas changes in oculomotor function can give us more evidence of cognitive functioning. Anyway, the visual functions are highly valuable for understanding the functional impact on neurological and certainly will ensure therapeutic rehabilitation processes more effective and scientifically sound. However, translational researches in those fields are rare and we have a lot of ground to walk on knowledge of brain phenomena in normal and disease.

\section{Acknowledgements}

I would like to thank Dora Fix Ventura for theoretical discussions and insights during all of the work. M.F.C. is a CNPq level 2 Fellow Researcher. I also would like to CNPq (401153/2009-6) for the financial support.

\section{References}

1. Crook JD, Davenport CM, Peterson BB, Packer OS, Detwiler PB, et al. (2009) Parallel ON and OFF cone bipolar inputs establish spatially coextensive receptive field structure of blue-yellow ganglion cells in primate retina. J Neurosci 29: 8372-8387

2. Dacey DM, Petersen MR (1992) Dendritic field size and morphology of midget and parasol ganglion cells of the human retina. Proc Natl Acad Sci U S A 89: 9666-9670.

3. Lee BB (2004) Paths to colour in the retina. Clin Exp Optom 87: 239-248.

4. Merigan WH (1989) Chromatic and achromatic vision of macaques: role of the P pathway. J Neurosci 9: 776-783.

5. Merigan WH, Maunsell JH (1993) How parallel are the primate visual pathways? Annu Rev Neurosci 16: 369-402.

6. Hendry SH, Reid RC (2000) The koniocellular pathway in primate vision. Annu Rev Neurosci 23: 127-153.

7. Xu X, Ichida JM, Allison JD, Boyd JD, Bonds AB, et al. (2001) A comparison of koniocellular, magnocellular and parvocellular receptive field properties in the lateral geniculate nucleus of the owl monkey (Aotus trivirgatus). J Physiol 531: 203-218.

8. Van Nieuwenhuizen O, Willemse J (1984) CT-scanning in children with cerebral visual disturbance and its possible relation to hypoxia and ischaemia. Behav Brain Res 14: 143-145.

9. Robinson RO (1973) The frequency of other handicaps in children with cerebra palsy. Dev Med Child Neurol 15: 305-312.

10. Hertz BG, Rosenberg J (1992) Effect of mental retardation and motor disability on testing with visual acuity cards. Dev Med Child Neurol 34: 115-122.

11. Schenk-Rootlieb AJ, van Nieuwenhuizen O, van der Graaf $Y$, Wittebol-Post $D$ 
Willemse J (1992) The prevalence of cerebral visual disturbance in children with cerebral palsy. Dev Med Child Neurol 34: 473-480.

12. Schenk-Rootlieb AJ, Van Nieuwenhuizen O, Schiemanck N, Van der Graaf Y, Willemse J (1993) Impact of cerebral visual impairment on the everyday life of cerebral palsied children. Child Care Health Dev 19: 411-423.

13. Erkkilä H, Lindberg L, Kallio AK (1996) Strabismus in children with cerebral palsy. Acta Ophthalmol Scand 74: 636-638.

14. Black $P$ (1982) Visual disorders associated with cerebral palsy. Br J Ophthalmo 66: 46-52.

15. Eken P, De Vries LS, van der GY, Meiners LC, Van Nieuwenhuizen O(1995) Haemorrhagic-ischaemic lesions of the neonatal brain: correlation between cerebral visual impairment, neurodevelopmental outcome and MRI in infancy. Dev Med Child Neurol 37:41-55.

16. Ferziger NB, Nemet P, Brezner A, Feldman R, Galili G, et al. (2011) Visua assessment in children with cerebral palsy: implementation of a functional questionnaire. Dev Med Child Neurol 53: 422-428.

17. Jacobson L, Ygge J, Flodmark O, Ek U (2002) Visual and perceptua characteristics, ocular motility and strabismus in children with periventricular leukomalacia. Strabismus 10: 179-183.

18. Lanzi G, Fazzi E, Uggetti C, Cavallini A, Danova S, et al. (1998) Cerebral visual impairment in periventricular leukomalacia. Neuropediatrics 29: 145-150.

19. Guzzetta A, Mercuri E, Cioni G (2001) Visual disorders in children with brain lesions: 2. Visual impairment associated with cerebral palsy. Eur J Paediatr Neurol 5: 115-119.

20. van Elk M, Crajé C, Beeren ME, Steenbergen B, van Schie HT, et al. (2010) Neural evidence for impaired action selection in right hemiparetic cerebral palsy. Brain Res 1349: 56-67.

21. Hoon AH Jr, Stashinko EE, Nagae LM, Lin DD, Keller J, et al. (2009) Sensory and motor deficits in children with cerebral palsy born preterm correlate with diffusion tensor imaging abnormalities in thalamocortical pathways. Dev Med Child Neurol 51: 697-704

22. Guzzetta A, Fazzi B, Mercuri E, Bertuccelli B, Canapicchi R, et al. (2001) Visual function in children with hemiplegia in the first years of life. Dev Med Child Neurol 43: 321-329.

23. Huo R, Burden SK, Hoyt CS, Good WV (1999) Chronic cortical visual impairment in children: aetiology, prognosis, and associated neurological deficits. $\mathrm{Br} \mathrm{J}$ Ophthalmol 83: 670-675.

24. Krägeloh-Mann I, Toft P, Lunding J, Andresen J, Pryds O, et al. (1999) Brain lesions in preterms: origin, consequences and compensation. Acta Paediatr 88: 897-908.

25. Hertz BG (1987) Acuity card testing of retarded children. Behav Brain Res 24 85-92.

26. Jacobson L, Ek U, Ygge J, Warburg M (2004) Visual impairment in children with brain damage: towards a diagnostic procedure? Dev Med Child Neurol 46: 67-68.

27. Costa MF, Ventura DF, Salomo SR, Berezovsky A, De Haro FMB, et al. (2001) Grating acuity measured by sweep VEP in children with spastic cerebral-palsy. Investigative Ophthalmology \& Visual Science 42:S787.

28. Costa MF, Haro-Munoz FM, Berezovsky A, Salomao SR, de Souza JM, et al. (2002) Grating acuity deficit and amblyopia by sweep-vep in children with spastic cerebral palsy. Investigative Ophthalmology \& Visual Science 43:U1323.

29. da Costa MF, Salomão SR, Berezovsky A, de Haro FM, Ventura DF (2004) Relationship between vision and motor impairment in children with spastic cerebral palsy: new evidence from electrophysiology. Behav Brain Res 149: $145-150$.

30. Westall CA, Ainsworth JR, Buncic JR (2000) Which ocular and neurologic conditions cause disparate results in visual acuity scores recorded with visually evoked potential and teller acuity cards? J AAPOS 4: 295-301.

31. Valberg A, Lee BB (1992) Main Cell Systems in Primate Visual Pathways. Current Opinion in Ophthalmology 3: 813-823.

32. Wolf JE, Arden GB, Plant GT (1996) Selective damage to either the "M" or "P" cell pathway in human retinal disease: implications for visual processing. Eur $\mathrm{J}$ Ophthalmol 6: 208-214.
33. Uggetti C, Egitto MG, Fazzi E, Bianchi PE, Bergamaschi R, et al. (1996) Cerebral visual impairment in periventricular leukomalacia: MR correlation. AJNR Am J Neuroradiol 17: 979-985.

34. Himmelmann K, Beckung E, Hagberg G, Uvebrant P (2006) Gross and fine motor function and accompanying impairments in cerebral palsy. Dev Med Child Neurol 48: 417-423.

35. Marozas DS, May DC (1986) Research on effects of color reversal on the visua perceptual and visuomotor performances of spastic cerebral palsied and other exceptional individuals. Percept Mot Skills 62: 595-607.

36. May DC (1978) Effects of color reversal of figure and ground drawing materials on drawing performance. Except Child 44: 254-260.

37. Sakuma Y (1971) [Studies on color vision defects in cerebral palsy]. Nihon Ganka Kiyo 22: 105-116.

38. Coltellaro J, LeGare M, Terdiman J (1995) Eye movements in a small sample of cerebral palsied adults. Percept Mot Skills 80: 355-369.

39. Fedrizzi E, Anderloni A, Bono R, Bova S, Farinotti M, et al. (1998) Eyemovement disorders and visual-perceptual impairment in diplegic children born preterm: a clinical evaluation. Dev Med Child Neurol 40: 682-688.

40. Matsuo M (1996) Duchenne/Becker muscular dystrophy: from molecular diagnosis to gene therapy. Brain Dev 18: 167-172.

41. Nobile C, Marchi J, Nigro V, Roberts RG, Danieli GA (1997) Exon-intron organization of the human dystrophin gene. Genomics 45: 421-424

42. O’Brien KF, Kunkel LM (2001) Dystrophin and muscular dystrophy: past, present, and future. Mol Genet Metab 74: 75-88.

43. O’Brien T, Harper PS, Davies KE, Murray JM, Sarfarazi M, et al. (1983) Absence of genetic heterogeneity in Duchenne muscular dystrophy shown by a linkage study using two cloned DNA sequences. J Med Genet 20: 249-251.

44. Hoffman EP, Brown RH, Kunkel LM Jr (1987) Dystrophin: the protein product of the Duchenne muscular dystrophy locus. Cell 51: 919-928.

45. Koenig M, Monaco AP, Kunkel LM (1988) The complete sequence of dystrophin predicts a rod-shaped cytoskeletal protein. Cell 53: 219-228.

46. Pillers DA (1999) Dystrophin and the retina. Mol Genet Metab 68: 304-309.

47. Pillers DA, Weleber RG, Green DG, Rash SM, Dally GY, et al. (1999) Effects of dystrophin isoforms on signal transduction through neural retina: genotypephenotype analysis of duchenne muscular dystrophy mouse mutants. Mo Genet Metab 66: 100-110.

48. Schmitz F, Holbach M, Drenckhahn D (1993) Colocalization of retinal dystrophin and actin in postsynaptic dendrites of rod and cone photoreceptor synapses. Histochemistry 100: 473-479.

49. Schmitz F, Drenckhahn D (1997) Dystrophin in the retina. Prog Neurobiol 53 547-560.

50. Schmitz F, Drenckhahn D (1997) Localization of dystrophin and betadystroglycan in bovine retinal photoreceptor processes extending into the postsynaptic dendritic complex. Histochem Cell Biol 108: 249-255.

51. Claudepierre T, Rodius F, Frasson M, Fontaine V, Picaud S, et al. (1999) Differential distribution of dystrophins in rat retina. Invest Ophthalmol Vis Sci 40: $1520-1529$.

52. Claudepierre T, Dalloz C, Mornet D, Matsumura K, Sahel J, et al. (2000) Characterization of the intermolecular associations of the dystrophinassociated glycoprotein complex in retinal Müller glial cells. J Cell Sci $113 \mathrm{Pt}$ 19: 3409-3417.

53. Claudepierre T, Mornet D, Pannicke T, Forster V, Dalloz C, et al. (2000) Expression of Dp71 in Müller glial cells: a comparison with utrophin- and dystrophin-associated proteins. Invest Ophthalmol Vis Sci 41: 294-304.

54. Connors NC, Kofuji P (2002) Dystrophin Dp71 is critical for the clustered localization of potassium channels in retinal glial cells. J Neurosci 22: 4321 4327.

55. Green DG, Pattnaik BR, Pillers DM (2004) Retinal glial cells contribute significantly to the negative ERG found in the mdxCv3 Duchenne muscular dystrophy mouse. Investigative Ophthalmology \& Visual Science 45:U601.

56. Green DG, Guo H, Pillers DA (2004) Normal photoresponses and altered b-wave responses to APB in the $\mathrm{mdx}(\mathrm{Cv} 3)$ mouse isolated retina ERG supports role for dystrophin in synaptic transmission. Vis Neurosci 21: 739-747. 
57. Ueda H, Baba T, Terada N, Kato Y, Tsukahara S, et al. (1997) Dystrophin in rod spherules; submembranous dense regions facing bipolar cell processes. Histochem Cell Biol 108: 243-248

58. Ueda H, Gohdo T, Ohno S (1998) Beta-dystroglycan localization in the photoreceptor and Müller cells in the rat retina revealed by immunoelectron microscopy. J Histochem Cytochem 46: 185-191.

59. Ueda H, Baba T, Ohno S (2000) Current knowledge of dystrophin and dystrophin-associated proteins in the retina. Histol Histopathol 15: 753-760.

60. D'Souza VN, Nguyen TM, Morris GE, Karges W, Pillers DA, et al. (1995) A novel dystrophin isoform is required for normal retinal electrophysiology. Hum Mol Genet 4: 837-842.

61. Fitzgerald KM, Cibis GW, Giambrone SA, Harris DJ (1994) Retinal signal transmission in Duchenne muscular dystrophy: evidence for dysfunction in the photoreceptor/depolarizing bipolar cell pathway. J Clin Invest 93: 2425-2430.

62. Fitzgerald KM, Cibis GW, White RA (1998) ERG in Duchenne/Becker muscular dystrophy. Pediatr Neurol 19: 400-401.

63. Fitzgerald KM, Cibis GW, Gettel AH, Rinaldi R, Harris DJ, et al. (1999) ERG phenotype of a dystrophin mutation in heterozygous female carriers of Duchenne muscular dystrophy. J Med Genet 36: 316-322.

64. Pillers DA, Seltzer WK, Powell BR, Ray PN, Tremblay F, et al. (1993) Negativeconfiguration electroretinogram in Oregon eye disease. Consistent phenotype in Xp21 deletion syndrome. Arch Ophthalmol 111: 1558-1563.

65. Pillers DA, Fitzgerald KM, Duncan NM, Rash SM, White RA, et al. (1999) Duchenne/Becker muscular dystrophy: correlation of phenotype by electroretinography with sites of dystrophin mutations. Hum Genet 105: 2-9.

66. Pillers DA, Bulman DE, Weleber RG, Sigesmund DA, Musarella MA, et al. (1993) Dystrophin expression in the human retina is required for normal function as defined by electroretinography. Nat Genet 4: 82-86.

67. Pillers DA, Weleber RG, Woodward WR, Green DG, Chapman VM, et al. (1995) mdxCv3 mouse is a model for electroretinography of Duchenne/Becker muscular dystrophy. Invest Ophthalmol Vis Sci 36: 462-466.

68. Pillers DA, Duncan NM, Dwinnell SJ, Rash SM, Kempton JB, et al. (1999) Normal cochlear function in $\mathrm{mdx}$ and $\mathrm{mdx}(\mathrm{Cv} 3)$ Duchenne muscular dystrophy mouse models. Laryngoscope 109: 1310-1312.

69. Pillers DM, Towbin JA, Chamberlain JS, Wu D, Ranier J, et al.(1989) Aland Island Eye Disease Localized by Molecular Genetic-Analysis to Xp21.3-P21.2 in A Patient with Duchenne Muscular-Dystrophy, Glycerol Kinase-Deficiency, Congenital Adrenal Hypoplasia, and A Chromosomal Deletion. Cytogenetics and Cell Genetics 51:1059-1060.

70. Tremblay F, De B, I, Riddell DC, Dooley JM (1994) Duchenne muscular dystrophy: negative scotopic bright-flash electroretinogram and normal dark adaptation. Can J Ophthalmol 29:280-283.

71. Tremblay F, Laroche RG, De Becker I (1995) The electroretinographic diagnosis of the incomplete form of congenital stationary night blindness. Vision Res 35: 2383-2393.

72. Tremblay F, De Becker I, Cheung C, LaRoche GR (1996) Visual evoked potentials with crossed asymmetry in incomplete congenital stationary night blindness. Invest Ophthalmol Vis Sci 37: 1783-1792.

73. Sigesmund DA, Weleber RG, Pillers DA, Westall CA, Panton CM, et al. (1994) Characterization of the ocular phenotype of Duchenne and Becker muscular dystrophy. Ophthalmology 101: 856-865.

74. Zatz M, Itskan SB, Sanger R, Frota-Pessoa O, Saldanha PH (1974) New linkage data for the $\mathrm{X}$-linked types of muscular dystrophy and G6PD variants, colour blindness, and Xg blood groups. J Med Genet 11: 321-327.

75. Costa MF, Ventura DF, Pavanello RCM, Cerqueira A, Zatz M (2004) Color vision phenotype in Duchenne Muscle Dystrophy. Investigative Ophthalmology \& Visual Science 45:424.

76. Costa MF, Oliveira AGF, Santana CF, Lago M, Zatz M (2005) Red-green color vision and luminance contrast sensitivity losses in Duchenne Muscular Dystrophy. Investigative Ophthalmology \& Visual Science 46:4576.

77. Costa MF, Oliveira AG, Feitosa-Santana C, Zatz M, Ventura DF (2007) Redgreen color vision impairment in Duchenne muscular dystrophy. Am J Hum Genet 80: 1064-1075.

78. Costa MF, Oliveira AG, Feitosa-Santana C, Zatz M, Ventura DF (2007) Red- green color vision impairment in Duchenne muscular dystrophy. Am J Hum Genet 80: 1064-1075.

79. Pillers DA, Fitzgerald KM, Duncan NM, Rash SM, White RA, et al. (1999) Duchenne/Becker muscular dystrophy: correlation of phenotype by electroretinography with sites of dystrophin mutations. Hum Genet 105: 2-9.

80. De Becker I, Riddell DC, Dooley JM, Tremblay F (1994) Correlation between electroretinogram findings and molecular analysis in the Duchenne muscular dystrophy phenotype. Br J Ophthalmol 78: 719-722.

81. Sigesmund DA, Ray PN, Pillers DM, Weleber RG, Westall CA, et al. (1993) Duchenne Muscular-Dystrophy (Dmd) - Severity of Rod Dysfunction Correlates with Location of Deletion in Dmd Gene. Investigative Ophthalmology \& Visual Science 34:1463.

82. Neitz M, Neitz J (2000) Molecular genetics of color vision and color vision defects. Arch Ophthalmol 118: 691-700.

83. Costa MF (2012) Phenotype of color vision as a divisor of possible sites of mutations or deletion points. Current Topics in Genetics 5:37-44.

84. Dobkins KR, Gunther KL, Peterzell DH (2000) What covariance mechanisms underlie green/red equiluminance, luminance contrast sensitivity and chromatic (green/red) contrast sensitivity? Vision Res 40: 613-628.

85. Dobkins KR, Anderson CM, Kelly J (2001) Development of psychophysicallyderived detection contours in L- and M-cone contrast space. Vision Res 41 1791-1807.

86. Benoff K, Fitzgerald K, Zemon V, Pinkhasov E, Gordon J, et al. (2001) Magnocellular ON-pathway deficits in Duchenne muscular dystrophy: A visual evoked potential study. Investigative Ophthalmology \& Visual Science 42:S787.

87. Costa MF, Barboni MT, Ventura DF (2011) Psychophysical measurements of luminance and chromatic spatial and temporal contrast sensitivity in Duchenne muscular dystrophy. Psychology \& Neuroscience 4:67-74.

88. Tzekov C, Cherninkova S, Gudeva T (1991) Neuroophthalmological symptoms in children treated for internal hydrocephalus. Pediatr Neurosurg 17: 317-320.

89. Cedzich C, Schramm J, Wenzel D (1990) Reversible visual loss after shunt malfunction. Acta Neurochir (Wien) 105: 121-123.

90. Biglan AW (1995) Strabismus associated with meningomyelocele. J Pediatr Ophthalmol Strabismus 32: 309-314.

91. Caines E, Dahl M (1997) Ophthalmological findings in a prospective study of 22 children with spina bifida cystica. Eur J Pediatr Surg 7 Suppl 1: 52-53.

92. Altintas O, Etus V, Etus H, Ceylan S, Caglar Y (2005) Risk of strabismus and ambylopia in children with hydrocephalus. Graefes Arch Clin Exp Ophthalmo 243: 1213-1217.

93. IplikcioÄŸlu AC, Ozer F, Erbengi A (1989) Upward-gaze palsy due to shunt malfunction. Neurosurgery 24: 141

94. Bogdanovic MD, Plant GT (2000) Chiasmal compression due to obstructive hydrocephalus. J Neuroophthalmol 20: 266-267.

95. Holsgrove D, Leach P, Herwadkar A, Gnanalingham KK (2009) Visual field deficit due to downward displacement of optic chiasm. Acta Neurochir (Wien) 151: 995-997.

96. Jacobson JH, Hirose T, Suzuki TA (1968) Simultaneous ERG and VER in lesions of the optic pathway. Invest Ophthalmol 7: 279-292.

97. Odebode TO, Shokunbi MT, Malomo AO, Familusi JB, Agbeja-Baiyeroju AM et al. (1998) The relationship between ventricular size and visual function in children with hydrocephalus. Afr J Med Med Sci 27: 213-218.

98. Sutton LN, Sun P, Adzick NS (2001) Fetal neurosurgery. Neurosurgery 48 124-142.

99. Heinsbergen I, Rotteveel J, Roeleveld N, Grotenhuis A (2002) Outcome in shunted hydrocephalic children. Eur J Paediatr Neurol 6: 99-107.

100. Kliemann SE, Rosemberg S (2005) [Shunted hydrocephalus in childhood: an epidemiological study of 243 consecutive observations]. Arq Neuropsiquiat 63: 494-501.

101. Pereira SA, Costa MF (2012) Visual acuity evaluation in children with hydrocephalus: An electrophysiological study with sweep visual evoked potential. World Journal of Neuroscience 2:36-43.

102. Frohman EM (2003) Multiple sclerosis. Med Clin North Am 87: 867-897, viii-ix. 
103. Frohman EM, Frohman TC, Zee DS, McColl R, Galetta S (2005) The neuroophthalmology of multiple sclerosis. Lancet Neurol 4: 111-121.

104. Volpe NJ (2001) Optic neuritis: historical aspects. J Neuroophthalmol 21: 302 309.

105. Volpe NJ, Rizzo JF 3rd, Lessell S (2001) Acute idiopathic blind spot enlargement syndrome: a review of 27 new cases. Arch Ophthalmol 119: 5963.

106. McDonald WI, Barnes D (1992) The ocular manifestations of multiple sclerosis. 1. Abnormalities of the afferent visual system. J Neurol Neurosurg Psychiatry 55: 747-752.

107.McDonald WI, Miller DH, Barnes D (1992) The pathological evolution of multiple sclerosis. Neuropathol Appl Neurobiol 18: 319-334.

108. Armstrong RA (1999) Multiple sclerosis and the eye. Ophthalmic Physiol Op 19 Suppl 2: S32-42.

109. Ashworth B, Aspinall PA, Mitchell JD (1989) Visual function in multiple sclerosis. Doc Ophthalmol 73: 209-224.

110. Beck RW, Cleary PA, Anderson MM Jr, Keltner JL, Shults WT, et al. (1992) A randomized, controlled trial of corticosteroids in the treatment of acute optic neuritis. The Optic Neuritis Study Group. N Engl J Med 326: 581-588.

111. Beck RW, Trobe JD, Moke PS, Brodsky MC, Buckley EG, et al. (1997) Visual function 5 years after optic neuritis experience of the Optic Neuritis Treatment Trial. Archives of Ophthalmology 115:1545-152.

112. Arden GB, Gucukoglu AG (1978) Grating test of contrast sensitivity in patients with retrobulbar neuritis. Arch Ophthalmol 96: 1626-1629.

113. Chen L, Gordon LK (2005) Ocular manifestations of multiple sclerosis. Curr Opin Ophthalmol 16: 315-320.

114. Chutorian AM (2003) [Acute loss of vision in children]. Rev Neurol 36: 264271.

115. Barnes D, McDonald WI (1992) The ocular manifestations of multiple sclerosis. 2. Abnormalities of eye movements. J Neurol Neurosurg Psychiatry 55: 863868.

116. Brodsky MC, Donahue SP, Vaphiades M, Brandt T (2006) Skew deviation revisited. Surv Ophthalmol 51: 105-128.

117. Warner J, Lessell S (1994) Neuro-ophthalmology of multiple sclerosis. Clin Neurosci 2: 180-188.

118. Starck M, Albrecht H, Pöllmann W, Dieterich M, Straube A (2010) Acquired pendular nystagmus in multiple sclerosis: an examiner-blind cross-over treatment study of memantine and gabapentin. J Neurol 257: 322-327.

119. Antal A, Aita JF, Bodis-Wollner I (2001) The paracentral visual field in multiple sclerosis: evidence for a deficit in interneuronal spatial summation? Vision Res 41: $1735-1742$.

120. Caruana PA, Davies MB, Weatherby SJ, Williams R, Haq N, et al. (2000) Correlation of MRI lesions with visual psychophysical deficit in secondary progressive multiple sclerosis. Brain 123 : 1471-1480.

121. Cheng H, Laron M, Schiffman JS, Tang RA, Frishman LJ (2007) The relationship between visual field and retinal nerve fiber layer measurements in patients with multiple sclerosis. Invest Ophthalmol Vis Sci 48: 5798-5805.

122. Frederiksen JL, Larsson HB, Ottovay E, Stigsby B, Olesen J (1991) Acute optic neuritis with normal visual acuity. Comparison of symptoms and signs with psychophysiological, electrophysiological and magnetic resonance imaging data. Acta Ophthalmol (Copenh) 69: 357-366.

123. Sekuler R, Owsley C, Berenberg R (1986) Contrast sensitivity during provoked visual impairment in multiple sclerosis. Ophthalmic Physiol Opt 6: 229-232.

124. Tulunay-Keesey U, Brooks BR, Kukuljan R, Ver Hoeve JN (1994) Effect of orientation on spatiotemporal contrast sensitivity in multiple sclerosis. Vision Res 34: 123-136.

125. Vighetto A, Grochowicki M, Cousin J (1990) [Spatial contrast sensitivity in multiple sclerosis]. Rev Neurol (Paris) 146: 264-270.

126. Vleugels L, van Nunen A, Lafosse C, Ketelaer P, Vandenbussche E (1998) Temporal and spatial resolution in foveal vision of multiple sclerosis patients. Vision Res 38: 2987-2997.

127. Vleugels L, Charlier M, van Nunen A, Lafosse C, Vogels R, et al. (1999)
Temporal resolution deficits in the visual fields of MS patients. Vision Res 39 : 2429-2438

128. Rocca MA, Filippi M (2007) Functional MRI in multiple sclerosis. J Neuroimaging 17 Suppl 1: 36S-41S.

129. Fallowfield L, Krauskopf J (1984) Selective loss of chromatic sensitivity in demyelinating disease. Invest Ophthalmol Vis Sci 25: 771-773.

130. Mullen KT, Plant GT (1986) Colour and luminance vision in human optic neuritis. Brain $109: 1-13$.

131. Flanagan P, Zele AJ (2004) Chromatic and luminance losses with multiple sclerosis and optic neuritis measured using dynamic random luminance contrast noise. Ophthalmic Physiol Opt 24: 225-233.

132. Flanagan P, Markulev C (2005) Spatio-temporal selectivity of loss of colour and luminance contrast sensitivity with multiple sclerosis and optic neuritis. Ophthalmic Physiol Opt 25: 57-65.

133. Barbur JL, Moro S, Harlow JA, Lam BL, Liu M (2004) Comparison of pupil responses to luminance and colour in severe optic neuritis. Clin Neurophysio 115: $2650-2658$.

134. Moura AL, Teixeira RA, Oiwa NN, Costa MF, Feitosa-Santana C, et al. (2008) Chromatic discrimination losses in multiple sclerosis patients with and without optic neuritis using the Cambridge Colour Test. Vis Neurosci 25: 463-468.

135. Ventura DF, Gualtieri M, Oliveira AG, Costa MF, Quiros P, et al. (2007) Male prevalence of acquired color vision defects in asymptomatic carriers of Leber's hereditary optic neuropathy. Invest Ophthalmol Vis Sci 48: 2362-2370.

136. Gualtieri M, Oliveira AGF, Canto-Pereira LHM, Costa MF, Salomao SR, et al.(2004) Sparing of the blue system in LHON (Leber's hereditary optic neuropathy). Investigative Ophthalmology \& Visual Science 45:424.

137. Gualtieri M, Nishi M, Lago M, Ventura DF (2005) Color discrimination and chromatic contrast sensitivity assessed in type 2 diabetic patients without retinopathy. Investigative Ophthalmology \& Visual Science 46:4750.

138. Gualtieri M, Bandeira M, Hamer RD, Costa MF, Oliveira AG, et al. (2008) Psychophysical analysis of contrast processing segregated into magnocellular and parvocellular systems in asymptomatic carriers of 11778 Leber's hereditary optic neuropathy. Vis Neurosci 25:469-474.

139. Ventura DF, Quiros P, Carelli V, Salomao SR, Gualtieri M, et al. (2005) Chromatic and luminance contrast sensitivities of carriers of 11778 Leber's Hereditary Optic Neuropathy (LHON) from a giant pedigree in Brazil. Investigative Ophthalmology \& Visual Science 46

140. Ventura DF, Simões AL, Tomaz S, Costa MF, Lago M, et al. (2005) Colou vision and contrast sensitivity losses of mercury intoxicated industry workers in Brazil. Environ Toxicol Pharmacol 19: 523-529.

141.Ventura DF, Quiros P, Carelli V, Salomão SR, Gualtieri M, et al. (2005) Chromatic and luminance contrast sensitivities in asymptomatic carriers from a large Brazilian pedigree of 11778 Leber hereditary optic neuropathy. Invest Ophthalmol Vis Sci 46: 4809-4814.

142. Cavalleri A, Belotti L, Gobba F, Luzzana G, Rosa P, et al. (1995) Colour vision loss in workers exposed to elemental mercury vapour. Toxicol Lett $77: 351$ 356.

143. Cavalleri A, Gobba F (1998) Reversible color vision loss in occupational exposure to metallic mercury. Environ Res 77: 173-177.

144. Gobba $F$ (2000) Color vision: a sensitive indicator of exposure to neurotoxins. Neurotoxicology 21: 857-862.

145. Silveira LCL, Damin ETB, Pinheiro MCN, Rodrigues AR, Moura ALA, et al (2003) Visual dysfunction following mercury exposure by breathing mercury vapour or by eating mercury-contaminated food. In: Mollon JD, Pokorny J, Knoblauch K, editors. Normal and Defective Colour Vision. Oxford, England Oxford University Press p. 407-417.

146. Urban P, Gobba F, Nerudová J, Lukás E, Cábelková Z, et al. (2003) Color discrimination impairment in workers exposed to mercury vapor. Neurotoxicology 24: 711-716.

147. Urban P, Nerudová J, Cábelková Z, Krajca V, Lukás E, et al. (2003) EEG photic driving in workers exposed to mercury vapors. Neurotoxicology 24: 2333.

148. Ventura DF, Costa MT, Costa MF, Berezovsky A, Salomão SR, et al. (2004) Multifocal and full-field electroretinogram changes associated with color-vision loss in mercury vapor exposure. Vis Neurosci 21: 421-429. 
149. Berlin M, Grant CA, Hellberg J, Hellström J, Schültz A (1975) Neurotoxicity of methylmercury in squirrel monkeys. Cerebral cortical pathology, interference with scotopic vision, and changes in operant behavior. Arch Environ Health 30: $340-348$.

150. Goralski H, Frol H (1979) [Encephalopathy after poisoning with organic mercury compounds]. Neurol Neurochir Pol 13: 371-376.

151. Korogi Y, Takahashi M, Shinzato J, Okajima T (1994) MR findings in seven patients with organic mercury poisoning (Minamata disease). AJNR Am J Neuroradiol 15: 1575-1578.

152. Abbaslou $P$, Zaman $T$ (2006) A Child with elemental mercury poisoning and unusual brain MRI findings. Clin Toxicol (Phila) 44: 85-88.

153.Fox DA, Sillman AJ (1979) Heavy metals affect rod, but not cone, photoreceptors. Science 206: 78-80.

154. Lebel J, Mergler D, Lucotte M, Amorim M, Dolbec J, et al. (1996) Evidence of early nervous system dysfunction in Amazonian populations exposed to lowlevels of methylmercury. Neurotoxicology 17: 157-167.

155. Lebel J, Mergler D, Branches F, Lucotte M, Amorim M, et al. (1998) Neurotoxic effects of low-level methylmercury contamination in the Amazonian Basin. Environ Res 79: 20-32.

156. Rodrigues AR, Souza CR, Braga AM, Rodrigues PS, Silveira AT, et al. (2007) Mercury toxicity in the Amazon: contrast sensitivity and color discrimination of subjects exposed to mercury. Braz J Med Biol Res 40: 415-424.

157. Grandjean P, Weihe P, Burse VW, Needham LL, Storr-Hansen E, et al. (2001) Neurobehavioral deficits associated with PCB in 7-year-old children prenatally exposed to seafood neurotoxicants. Neurotoxicol Teratol 23: 305-317.

158. Hudnell HK, Skalik I, Otto D, House D, Subrt P, et al. (1996) Visual contras sensitivity deficits in Bohemian children. Neurotoxicology 17: 615-628.

159. Ventura DF, Simoes AL, Costa MTV, Costa MF, de Souza JM, et al. (2003) Occupational mercury contamination produces loss of color-and contrastvision but no effect in full field ERG. Investigative Ophthalmology \& Visual Science 44:U445.

160. Costa MF, Tomaz S, de Souza JM, Silveira LC, Ventura DF (2008) Electrophysiological evidence for impairment of contrast sensitivity in mercury vapor occupational intoxication. Environ Res 107: 132-138.

161. Canto-Pereira LH, Lago M, Costa MF, Rodrigues AR, Saito CA, et al. (2005) Visual impairment on dentists related to occupational mercury exposure. Environ Toxicol Pharmacol 19: 517-522.

162. Altmann L, Sveinsson K, Krämer U, Weishoff-Houben M, Turfeld M, et al. (1998) Visual functions in 6-year-old children in relation to lead and mercury levels. Neurotoxicol Teratol 20: 9-17.

163. Gobba F, Cavalleri A (2003) Color vision impairment in workers exposed to neurotoxic chemicals. Neurotoxicology 24: 693-702.

164. Warfvinge K, Bruun A (1996) Mercury accumulation in the squirrel monkey eye after mercury vapour exposure. Toxicology 107: 189-200.

165. Warfvinge K, Bruun A (2000) Mercury distribution in the squirrel monkey retina after in Utero exposure to mercury vapor. Environ Res 83: 102-109.

166. Piikivi L, Hänninen H, Martelin T, Mantere P (1984) Psychological performance and long-term exposure to mercury vapors. Scand J Work Environ Health 10: 35-41.

167. Piikivi L, Tolonen U (1989) EEG findings in chlor-alkali workers subjected to low long term exposure to mercury vapour. Br J Ind Med 46: 370-375.

168. Piikivi L, Hänninen $H$ (1989) Subjective symptoms and psychological performance of chlorine-alkali workers. Scand J Work Environ Health 15: 6974.

169. Cockerham GC, Lemke S, Glynn-Milley C, Zumhagen L, Cockerham KP (2013) Visual performance and the ocular surface in traumatic brain injury. Ocul Surf 11: 25-34.

170. Alvarez TL, Kim EH, Vicci VR, Dhar SK, Biswal BB, et al. (2012) Concurrent vision dysfunctions in convergence insufficiency with traumatic brain injury. Optom Vis Sci 89: 1740-1751.

171.Dhaliwal A, West AL, Trobe JD, Musch DC (2006) Third, fourth, and sixth cranial nerve palsies following closed head injury. J Neuroophthalmol 26: 4-10.

172.Wang Q, Lu XJ, Ji WY, Yan ZC, Xu J, et al. (2010) Visual outcome after extended endoscopic endonasal transsphenoidal surgery for tuberculum sellae meningiomas. World Neurosurg 73: 694-700.

173. Chowdhury RK, Gupta N, Padhy KC (2009) An unusual case of total ophthalmoplegia. Indian J Ophthalmol 57: 389-391.

174. Marriott E, Jay WM (2007) Traumatic bitemporal hemianopia. Semin Ophthalmol 22: 3-7.

175. Lee KY, Tow S, Fong KS (2006) Visual recovery following emergent orbital decompression in traumatic retrobulbar haemorrhage. Ann Acad Med Singapore 35: 831-832.

176. Chirapapaisan N, Sadun AA (2005) A traumatic bitemporal hemianopia with macular sparing. J Med Assoc Thai 88 Suppl 9: S126-130.

177. Gassmann K, Hoffmann KT, Dietze U (2006) [Impaired color perception after a gunshot wound to the head]. Ophthalmologe 103: 1050-1052.

178. Brady S (2002) Sudden visual loss after closed head injury. Emerg Med J 19 475-476.

179. Ciuffreda KJ, Yadav NK, Han E, Ludlam DP, Peddle A, et al. (2012) Distance perception in mild traumatic brain injury (mTBI). Optometry 83: 127-136.

180. Thiagarajan P, Ciuffreda KJ, Ludlam DP (2011) Vergence dysfunction in mild traumatic brain injury (mTBI): a review. Ophthalmic Physiol Opt 31: 456-468.

181. Kapoor N, Ciuffreda KJ, Han Y (2004) Oculomotor rehabilitation in acquired brain injury: a case series. Arch Phys Med Rehabil 85: 1667-1678.

182. Schrupp LE, Ciuffreda KJ, Kapoor N (2009) Foveal versus eccentric retina critical flicker frequency in mild traumatic brain injury. Optometry 80: 642-650.

183. Ciuffreda KJ, Han Y, Kapoor N, Ficarra AP (2006) Oculomotor rehabilitation for reading in acquired brain injury. NeuroRehabilitation 21: 9-21.

184. Han Y, Ciuffreda KJ, Kapoor N (2004) Reading-related oculomotor testing and training protocols for acquired brain injury in humans. Brain Res Brain Res Protoc 14: 1-12

185. Jones NS (1997) Visual evoked potentials in endoscopic and anterior skul base surgery: a review. J Laryngol Otol 111: 513-516.

186. Saito H, Kanayama S, Takahashi T (1992) Right angular lesion and selective impairment of motion vision in left visual field. Tohoku J Exp Med 166: 229 238.

187. Alam M, Iqbal M, Khan A, Khan SA (2012) Ocular injuries in blast victims. J Pak Med Assoc 62: 138-142.

188. Striem-Amit E, Guendelman M, Amedi A (2012) 'Visual' acuity of the congenitally blind using visual-to-auditory sensory substitution. PLoS One 7: e33136.

189. Romano JG (2009) Progress in rehabilitation of hemianopic visual field defects. Cerebrovasc Dis 27 Suppl 1: 187-190.

190. Romano JG, Schulz P, Kenkel S, Todd DP (2008) Visual field changes after a rehabilitation intervention: vision restoration therapy. J Neurol Sci 273: 70-74.

191. Khan S, Leung E, Jay WM (2008) Stroke and visual rehabilitation. Top Stroke Rehabil 15: 27-36.

192. Wester ST, Rizzo JF 3rd, Balkwill MD, Wall C 3rd (2007) Optokinetic nystagmus as a measure of visual function in severely visually impaired patients. Invest Ophthalmol Vis Sci 48: 4542-4548.

193. Bergman B, Sjöstrand J (2002) A longitudinal study of visual acuity and visual rehabilitation needs in an urban Swedish population followed from the ages of 70 to 97 years of age. Acta Ophthalmol Scand 80: 598-607.

194.Gieser DK (1992) Visual rehabilitation. The challenge, responsibility, and reward. Ophthalmology 99: 1622-1625.

195. Bailey KL (1991) Low vision: the forgotten treatment. J Ophthalmic Nurs Technol 10: 103-105.

196. Costa MF, Ventura DF (2012) Visual impairment in children with spastic cerebral palsy measured by psychophysical and electrophysiological grating acuity tests. Dev Neurorehabil 15: 414-424.

197. Alvarez GA, Cavanagh P (2005) Independent resources for attentional tracking in the left and right visual hemifields. Psychol Sci 16: 637-643.

198. Armann R, Bülthoff I (2009) Gaze behavior in face comparison: the roles of sex, task, and symmetry. Atten Percept Psychophys 71: 1107-1126. 
199. Bayliss AP, Griffiths D, Tipper SP (2009) Predictive gaze cues affect face evaluations: The effect of facial emotion. Eur J Cogn Psychol 21: 1072-1084.

200.Blake R, Turner LM, Smoski MJ, Pozdol SL, Stone WL (2003) Visual recognition of biological motion is impaired in children with autism. Psychol Sci 14: 151-157.

201. Bouvier SE (2009) Top-down influences of spatial attention in visual cortex. J Neurosci 29: 1597-1598.

202. Brunel L, Lesourd M, Labeye E, Versace R (2010) The sensory nature of knowledge: Sensory priming effects in semantic categorization. Q J Exp Psychol (Hove) 63: 955-964.

203. Calder AJ, Lawrence AD, Keane J, Scott SK, Owen AM, et al. (2002) Reading the mind from eye gaze. Neuropsychologia 40: 1129-1138.
204. Casco C, Grieco A, Campana G, Corvino MP, Caputo G (2005) Attention modulates psychophysical and electrophysiological response to visual texture segmentation in humans. Vision Res 45: 2384-2396.

205. Barboni MT, Feitosa-Santana C, Zachi EC, Lago M, Teixeira RA, et al. (2009) Preliminary findings on the effects of occupational exposure to mercury vapor below safety levels on visual and neuropsychological functions. J Occup Environ Med 51: 1403-1412.

206.Zachi EC, D F V, Faria MA, Taub A (2007) Neuropsychological dysfunction related to earlier occupational exposure to mercury vapor. Braz J Med Bio Res 40: 425-433
This article was originally published in a special issue, Neurorehabilitation \& Neural Repair handled by Editor(s). Dr. Hsinlin Thomas Cheng, University of Michigan, USA 